\title{
Risk Evaluation of Early-stage Hormone Receptor- positive and Human Epidermal Growth Factor Receptor 2-negative Breast Cancer Patients: a Population-based Study From Taiwan
}

Lei Lei

Chinese Academy of Sciences

Han-Ching Chan

National Taiwan University College of Public Health

Tzu-Pin Lu

National Taiwan University College of Public Health

Hung-Chun Skye Cheng ( $\nabla$ skye@kfsyscc.org )

Koo Foundation Sun Yat-Sen Cancer Center https://orcid.org/0000-0002-5331-6688

\section{Research Article}

Keywords: human epidermal growth factor receptor 2, breast cancer, Dutch criteria, Taiwan

Posted Date: June 22nd, 2021

DOI: https://doi.org/10.21203/rs.3.rs-626553/v1

License: (c) (1) This work is licensed under a Creative Commons Attribution 4.0 International License.

Read Full License

Version of Record: A version of this preprint was published at Breast Cancer Research and Treatment on July 19th, 2021. See the published version at https://doi.org/10.1007/s10549-021-06330-4. 


\section{Abstract}

\section{PURPOSE:}

To assess the prognostic value of the Dutch criteria for patients with early-stage hormone receptorpositive and human epidermal growth factor receptor 2-negative breast cancer from the Taiwan Cancer Database.

\section{PATIENTS AND METHODS:}

We included 8,295 patients with early-stage node-negative breast cancer who underwent surgery during January 2008-December 2012. Patients were stratified into low- and high-risk groups based on the Dutch criteria. The Kaplan-Meier method and log-rank test were used to estimate the difference in breast cancer-specific survival (BCSS) and overall survival (OS) between groups. Multivariable analysis was used to evaluate the prognostic value of the Dutch criteria.

\section{RESULTS:}

Overall, the low-risk and high-risk groups comprised 5,375 and 2,920 patients, respectively. In the low- and high-risk groups, the 5-year BCSS rate was $99.6 \%$ and $98.2 \%(P<0.0001)$ and the 5-year OS rate was 98.3\% and $96.8 \%(P<0.0001)$, respectively. The hazard ratio for BCSS was 4.18 (95\% confidence interval $[\mathrm{Cl}], 2.63-6.63, P<0.0001)$, and the hazard ratio for OS was 1.94 (95\% $\mathrm{Cl}, 1.48-2.55)$; both were significantly poorer in the high-risk group than in the low-risk group. In the low-risk group, the 5-year BCSS and OS of patients who did and did not receive adjuvant chemotherapy were similar $(99.5 \%$ versus $99.6 \%$ $[P=0.927]$ and $98.8 \%$ and $98.1 \%[P=0.0683]$, respectively).

\section{CONCLUSIONS:}

The prognosis of low-risk patients as classified using the Dutch criteria is excellent with or without adjuvant chemotherapy. The benefit of multi-gene testing for chemotherapy decision-making might be minimal in these patients.

\section{Introduction}

Breast cancer is the most common malignant disease in women, causing approximately 630,000 deaths worldwide in 2018 [2]. Hormone receptor-positive (HR+) and human epidermal growth factor receptor 2negative (HER2-) breast cancer is the most common subtype of breast cancer, accounting for approximately $60 \%$ of all breast cancer cases [7]. The biological nature of and postsurgical treatment strategies for early-stage HR + and HER2- breast cancer are very different from those of other breast cancer subtypes. HR + and HER2- breast cancer has a sustained risk of disease recurrence and death for at least 15 years after diagnosis, and most patients are treated with long-term endocrine therapy following adjuvant chemotherapy [6]. 
One of the biggest challenges in treating patients with early stage HR + and HER2- breast cancer is identifying high-risk patients who could benefit from adjuvant chemotherapy [15]. Numerous commercial multi-gene prediction models have been developed to guide decision-making for adjuvant chemotherapy in low-risk patients without medical concerns $[4,10,13,14,18]$. Despite the superior risk prediction performance of genomic-level models, clinicopathological factors still play an important role; for instance, the 70-gene signature (MammaPrint) in the MINDACT trial divided patients into clinical low- and high-risk groups (Dutch criteria) and demonstrated that clinically low-risk patients would not benefit from genomic testing [4]. Recently, the value of clinical risk criteria was examined in the well-known 21-gene test (Oncotype DX) in the TAILORx trial [19] in which only $8.9 \%(589 / 6616)$ of clinically low-risk patients had a recurrence score $>25$. Although the authoritative guideline endorses the Oncotype DX test to guide adjuvant therapy decision-making for patients with early stage HR + and HER2- breast cancer [8], the clinical criterion to undergo this testing is tumor size greater than $0.5 \mathrm{~cm}$. Consequently, excessive testing might be performed. Moreover, this kind of testing is related to a patient's income (patients with a higher income would have a higher testing rate; the current estimated cost is $\sim \$ 4,000$ ) and is available to about one-third of eligible patients in the United States [16]. Furthermore, a recent study using the Connecticut Tumor Registry revealed that the Oncotype DX was not cost effective for patients with low-risk breast cancer [21]. In Asian countries, these global commercial multi-gene models are desperately needed but are unavailable for many reasons, including racial differences in tumor biology and survival $[9,11]$. health beliefs, insurance coverage, and limited quality control of available tests [1]. Therefore, using clinical risk scales to identify patients with early-stage HR + and HER2- breast cancer who may have excellent survival after surgery and may not benefit from adjuvant chemotherapy is still worthwhile, especially in resource-constrained areas.

The prognostic value of the clinical risk scale (Dutch criteria) initially was adapted from Dutch CBO guidelines in 2004; it had a 70\% concordance with MammaPrint [3]. These criteria were then used in the TAILORX and MINDACT trials, but they have not been examined in a large cohort of patients with breast cancer. We assume that if the Dutch criteria could help identify a subgroup of patients with breast cancer who had excellent outcomes, then expensive multi-gene tests could be omitted for these low-risk patients. Therefore, we conducted a retrospective study to evaluate the prognostic value of the Dutch criteria using a cancer database in Taiwan.

\section{Materials And Methods}

\section{Eligibility}

We retrospectively evaluated patients with lymph node-negative, HR+, and HER2- invasive breast cancer initially treated with primary surgery and registered in the Taiwan Cancer Database (TCDB) between January 2008 and December 2012. The included patients with breast cancer met the following criteria: (1) pathologic stage T1-2 and node-negative disease, (2) HR positive, (3) HER2 negative, and (4) complete data on tumor grade and tumor size. Patients who had undergone preoperative chemotherapy and those with node-positive, pT3-4, cM1, or synchronous bilateral breast cancers were excluded. 
This study was reviewed and approved by the Institutional Review Board of National Taiwan University Hospital (NTUH-REC No.: 201910027W). The requirement for informed consent was waived because the data in the cancer registry were deidentified. Information acquired from the national database included age at diagnosis, histological grade, tumor stage, nodal stage, metastasis, ER/PR/HER2 status, and adjuvant therapies. The Consolidated Standards of Reporting Trials diagram is shown in Fig. 1. We included patients who underwent primary surgery in the form of either mastectomy or breast-conserving surgery and received adjuvant systemic therapy according to the routine clinical practice during that period. Adjuvant systemic therapy included endocrine therapy, chemotherapy, and radiotherapy.

\section{Risk classification and survival endpoints}

We used the binary clinical risk classification system based on the modified Adjuvant! algorithm used in the MINDACT and TAILORx trials [4][17]. The clinical low-risk scale (Dutch criteria) was defined as follows: age $>35$ years and grade 1 tumor measuring $\leq 3 \mathrm{~cm}$, grade 2 tumor measuring $\leq 2 \mathrm{~cm}$, or grade 3 tumor measuring $\leq 1 \mathrm{~cm}$; all other patients were categorized as high risk [3]. The primary study endpoint was breast cancer-specific survival (BCSS), which was defined as the interval from breast cancer surgery until death owing to breast cancer. The secondary endpoint was overall survival (OS), which was defined as the interval from breast cancer surgery until death owing to any cause. The last follow-up information was obtained from the TCDB and national death certification system in December 2019.

\section{Statistical analysis}

Statistical analysis was conducted using R (v.3.6.1) [20]. Differences in continuous data were calculated using the chi-square test, and $P$ values $<0.05$ were considered statistically significant. The 5 -year BCSS and 5-year OS rates were defined as survival endpoints for survival analysis, and differences in survival between the low- and high-risk groups were calculated using the Kaplan-Meier method and log-rank test. Univariate and multivariate analyses of the prognostic value of the Dutch criteria were performed using Cox proportional hazards analysis.

\section{Results}

\section{Patient characteristics}

There were 90,837 patients newly diagnosed with primary invasive breast cancer during the study periods in the TCDB registries. Among them, 8,295 (9.1\%) patients having pT1-2, node-negative, HR+, and HER2breast cancer were included in this study (Fig. 1). The baseline characteristics of all patients are listed in Table 1. The median age of patients with a high risk was less than that of patients with a low risk (52 years vs. 55 years, $P<0.001)$. Compared with high-risk patients, low-risk patients were less likely to have T2 tumors, grade 3 tumors, and stage II disease (all $P<0.001$ ). They were also less likely to have received adjuvant chemotherapy and radiotherapy but were more likely to have undergone endocrine therapy (all $P<0.001)$. 
Table 1

Baseline information of patients in the conservative cohort

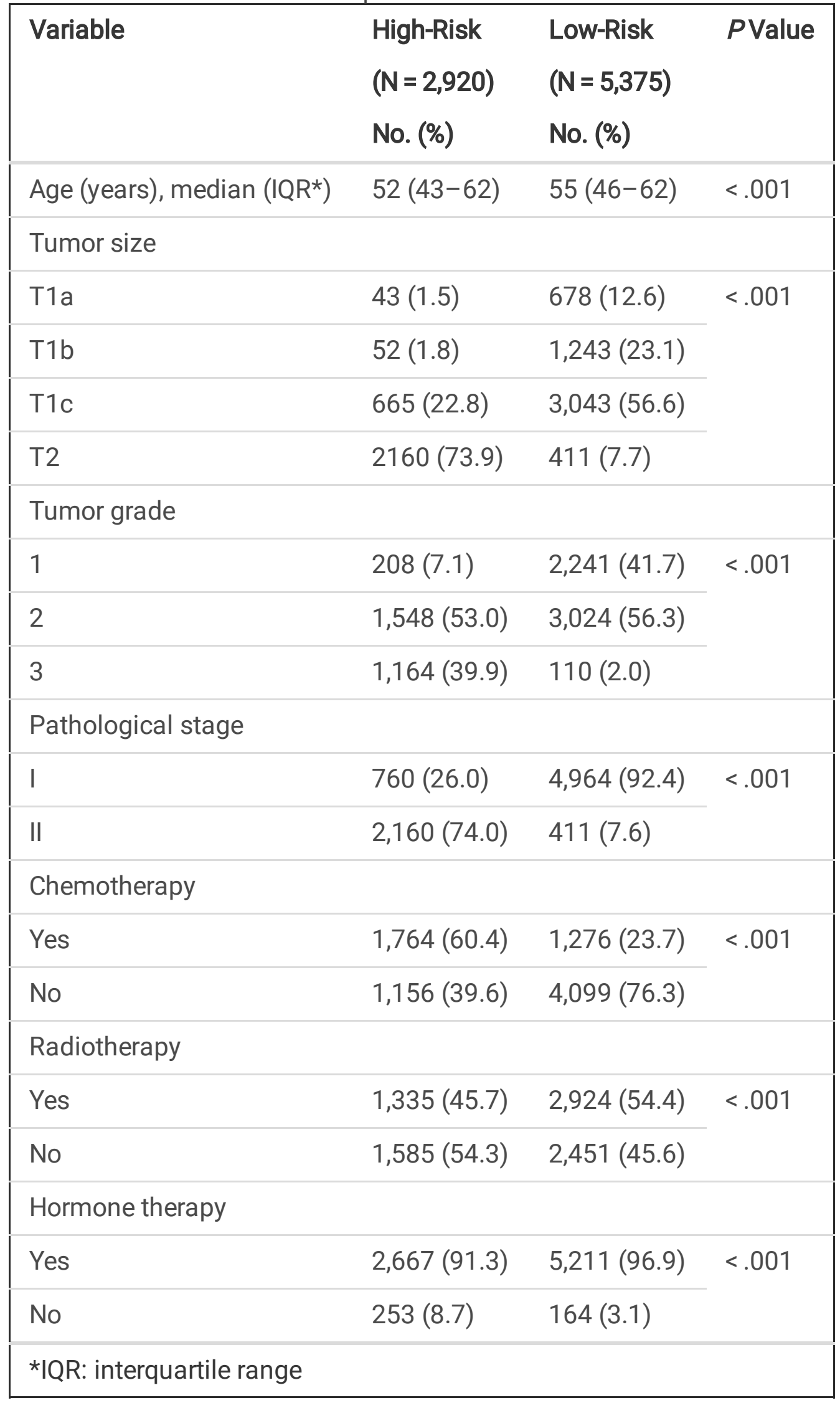

\section{Survival analyses}


The median follow-up interval of the entire cohort was 4.2 years (range: $0.1-7$ years). In the low-risk and high-risk groups, the 5-year BCSS rates were $99.6 \%(95 \% \mathrm{Cl}$, 99.4-99.8\%) and $98.2 \%(95 \% \mathrm{Cl}, 97.7-$ $98.7 \%)$, respectively $(P<0.0001)$, and the 5 -year OS rates were $98.3 \%(95 \% \mathrm{Cl}, 98.0-98.6 \%)$ and $96.8 \%$ (95\% Cl, 96.2-97.4\%), respectively $(P<0.0001)$ (Figs. 2A-2B).

In the low-risk group, the 5-year BCSS rates of patients who did and did not receive adjuvant chemotherapy were $99.5 \%(95 \% \mathrm{Cl}, 99.1-99.9 \%)$ and $99.6 \%(95 \% \mathrm{Cl}, 99.4-99.8 \%)$, respectively $(P=$ 0.8927); the 5-year OS rates were $98.8 \%(95 \% \mathrm{Cl}, 98.2-99.4 \%)$ and $98.1 \%(95 \% \mathrm{Cl}, 97.7-98.5 \%)$, respectively $(P=0.0676)$ (Figs. 3 and 4$)$.

In the high-risk group, the 5-year BCSS rates of patients with and without adjuvant chemotherapy were $98.4 \%(95 \% \mathrm{Cl}, 97.8-99.0 \%)$ and $97.8 \%(95 \% \mathrm{Cl}, 97.0-98.6 \%)$, respectively $(P=0.257)$. The absolute difference was $0.6 \%(P=0.257)$; the magnified figure shows a trend toward significance (Fig. 3). The 5year OS rates of patients with or without chemotherapy were $97.6 \%(95 \% \mathrm{Cl}, 96.9-98.3 \%)$ and $95.5 \%$ $(95 \% \mathrm{Cl}, 94.3-96.7 \%)$, respectively $(P=0.0027)$. The absolute difference in the $0 \mathrm{~S}$ rate at 5 years was $2.1 \%$ (Fig. 4, magnified figure).

Considering low-risk patients who received chemotherapy as a reference, hazard ratios for the 5-year breast cancer-specific mortality in high-risk patients with or without adjuvant chemotherapy were 3.527 $(P=0.0025)$ and $4.781(P=0.0002)$, respectively, and those for 5-year overall mortality were $2.175(P=$ $0.0046)$ and $3.892(P<0.0001)$, respectively (Table 2$)$. The hazard ratios for overall mortality in low-risk patients with and without chemotherapy were $1.606(P=0.068)$ and $1.791(P=0.0027)$ in high-risk patients.

Table 2

Low- and high-risk groups defined using the Dutch criteria with and without adjuvant chemotherapy

\section{Endpoint and risk group Patient \# Event Hazard ratio $P$ value Hazard ratio $P$ value}

\section{Breast cancer-specific survival}

\begin{tabular}{|c|c|c|c|c|c|c|}
\hline Low risk, chemo & 1276 & 7 & 1 & & 1 & \\
\hline Low risk, no chemo & 4099 & 16 & 0.9421 & 0.8927 & 0.96 & 0.927 \\
\hline High risk, chemo & 1764 & 28 & 3.5271 & 0.0025 & 1 & \\
\hline High risk, no chemo & 1156 & 25 & 4.7812 & 0.0002 & 1.349 & 0.257 \\
\hline \multicolumn{7}{|l|}{ Overall survival } \\
\hline Low risk, chemo & 1276 & 15 & 1 & & 1 & \\
\hline Low risk, no chemo & 4099 & 76 & 1.608 & 0.0676 & 1.606 & 0.0683 \\
\hline High risk, chemo & 1764 & 42 & 2.175 & 0.0046 & 1 & \\
\hline High risk, no chemo & 1156 & 52 & 3.892 & $<0.0001$ & 1.791 & 0.0027 \\
\hline
\end{tabular}




\section{Multivariate survival analysis}

Univariate analysis revealed that age at diagnosis, tumor size, and histology grade were significant prognostic factors. After adjusting these clinical risk factors and adjuvant treatments, the multivariate survival analysis (Model I) showed that high risk as defined using the Dutch criteria was the only independent negative predictor of both BCSS (hazard ratio 4.18 [2.63-6.63], $P<0.0001$ ) and OS (1.94 [1.48-2.55], $P<0.0001)$; the concordance index to predict outcomes was 0.76 and 0.63 , respectively (Table 3). If we did not include the Dutch criteria in the model, age at diagnosis, tumor size, and histology grade (Model II) were significantly associated with BCSS and OS (Table 3). Patients aged $\leq 35$ years had a poorer BCSS (hazard ratio 2.44, 1.22-4.87, $P=0.0117$ ) but not OS (hazard ratio $0.96,0.49-1.87, P=$ 0.9027). The hazard ratios for tumor size (per cm increment) with respect to BCSS and OS were 1.05 and $1.04, P=0.0006$ and $<0.0001$, respectively. Using grade 1 as a reference, grade 2 and grade 3 were also independent prognostic factors of BCSS and OS (Table 3).

Table 3

Multivariate survival analyses for the entire cohort

\begin{tabular}{|c|c|c|c|c|}
\hline & \multicolumn{2}{|c|}{ Breast cancer-specific survival } & \multicolumn{2}{|l|}{ Overall survival } \\
\hline & Model I & & & \\
\hline Variable & Hazard ratio $(95 \% \mathrm{Cl})$ & $P$ value & Hazard ratio $(95 \% \mathrm{Cl})$ & $P$ value \\
\hline Low risk & 1 & & 1 & \\
\hline High risk & $4.18(2.63-6.63)$ & $<0.0001$ & $1.94(1.48-2.55)$ & $<0.0001$ \\
\hline \multirow[t]{2}{*}{ C-index } & 0.68 & & 0.58 & \\
\hline & Model II & & & \\
\hline \multicolumn{5}{|l|}{ Age } \\
\hline$>35$ years & 1 & & 1 & \\
\hline$\leq 35$ years & $2.44(1.22-4.87)$ & 0.0117 & $0.96(0.49-1.87)$ & 0.9027 \\
\hline Size $(\mathrm{cm})$ & $1.05(1.03-1.07)$ & $<0.0001$ & $1.04(1.03-1.05)$ & $<0.0001$ \\
\hline \multicolumn{5}{|l|}{ Grade } \\
\hline Grade 1 & 1 & & 1 & \\
\hline Grade 2 & $2.61(1.23-5.54)$ & 0.0129 & $1.44(1.00-2.08)$ & 0.0477 \\
\hline Grade 3 & $5.60(2.58-12.17)$ & $<0.0001$ & $2.00(1.32-3.05)$ & 0.0011 \\
\hline C-index & 0.75 & & 0.63 & \\
\hline
\end{tabular}




\section{Discussion}

In the era of multi-gene expression panel-guided adjuvant systemic therapy, the use of conventional clinical and pathological risk factors to predict response to therapy should not be dismissed for patients with early stage HR + and HER2- breast cancer. In this study, we affirmed the prognostic value of the clinical risk scale (Dutch criteria) adopted in previous clinical trials in a real-world study of a nodenegative breast cancer population in Taiwan. The Dutch criteria defined a subset of patients with nodenegative, HR+, and HER2- breast cancer whose 5-year BCSS was greater than 99\% (Fig. 2). Additionally, the 5 -year OS of those patients was above $98 \%$, which is very similar to the released data of patients with a recurrence score $\leq 25$ by the Oncotype DX test in the TAILORx trial [17]. In the low-risk group, no significant survival benefit was observed with adjuvant chemotherapy after a minimum 5-year follow-up period. The independent prognostic value of the Dutch criteria was also confirmed in the multivariate analysis (Table 3). Finally, though there was a significant difference in survival based on the administration of chemotherapy in the entire cohort, the survival benefit in the clinically high-risk setting was minimal, reflecting the lack of predictive value of the Dutch criteria for guiding adjuvant chemotherapy. Altogether, our findings suggest that the National Comprehensive Cancer Network (NCCN) guidelines should supersede the recommendation of the Oncotype DX test only for clinically high-risk patients for cost considerations. This recommendation is especially meaningful for medical care in lowor medium-income areas.

Though the 21-gene signature is widely accepted for adjuvant chemotherapy decision-making for all patients with early stage HR + and HER2- breast cancer, the latest NCCN guideline recommends its use for women with tumors measuring $>0.5 \mathrm{~cm}$. However, for tumors with low-grade histology and no lymphovascular invasion, physicians can decide whether to perform gene signature testing [8]. Another commercial and widely approved multi-gene expression test is the 70-gene test. Though this test has different genomic algorithms than the Oncotype DX, it was originally used for clinical risk evaluation and has proven that clinically low-risk patients did not benefit from adjuvant chemotherapy, regardless of whether they had a high genomic risk [5]; thus, it is more rational based on our results that only clinically high-risk patients would potentially benefit from genomic testing because clinically low-risk patients had favorable outcomes. Data supporting the value of clinical risk evaluation beyond genomic testing in the TAILORx trial were recently released and revealed that clinically low-risk patients were mainly genomically low-risk [19]. Though the application of genomic testing for patients with lymph node-positive breast cancer is currently being examined in clinical trials [5] [12], our data confirm that among lymph nodenegative patients, those who could benefit from expensive multi-gene expression signature tests should be prioritized.

Some limitations and cautions regarding this study need to be discussed. First, this was a retrospective population-based study, and our conclusion could have some uncontrolled biases. The broad application of systemic therapy makes it difficult to obtain information on patients who did not receive such therapies. Second, having recurrence-related endpoints in addition to BCSS and OS would have improved the survival analysis in our study. Unfortunately, we were restrained by preserved documents in this labor- 
intensive established national database search. Therefore, we focused on BCSS because understanding the risk of BCSS is the first step in clinical practice to make an informed treatment decision. Third, information on comorbid conditions was not included in the national registry; patients without chemotherapy might have poorer performance. Therefore, there was a small difference in the OS of lowrisk patients with and without chemotherapy ( $98.8 \%$ versus $98.1 \%$, Fig. 4); however, this difference was not observed in BCSS (99.5\% versus $99.6 \%$, Fig. 3). Additionally, the potential relatively long-term survival of patients with HR + and HER2- breast cancer and the competing risk of death might dilute the prognostic value of OS. Our inclusion of BCSS as an endpoint is therefore vital. Finally, age-specific differences in survival should be examined. We examined the effect of age in the low-risk subgroup and observed a significant difference based on age ( $<50$ vs. $\geq 50$ years) in OS ( $98.7 \%$ versus $95.9 \%, P=$ $0.0009)$ but not in BCSS (99.1\% versus $98.9 \%, P=0.7578)$. This conclusion is understandable, as older patients would have worse OS than younger patients.

\section{Conclusion}

The benefit of chemotherapy in low-risk patients as defined using the Dutch criteria might be minimal because breast cancer mortality was $<1 \%$ with a minimum 5-year follow-up. Therefore, we do not recommend multi-gene testing for these patients, as it would not be cost effective. High risk as defined using the Dutch criteria was an independent negative factor in survival analysis. More data are warranted to confirm our conclusion.

\section{Declarations}

\section{Acknowledgments}

This study was kindly supported by grants from the Ministry of Science and Technology, Taipei, Taiwan (MOST 105-2314-B-368-001), and the Zhejiang public welfare technology research program (LGJ20H160001).

\section{Funding}

This work was supported by grants from the Ministry of Science and Technology, Taipei, Taiwan (MOST 105-2314-B-368-001), Hammer Family Fund (2018-2020), and the Zhejiang Public Welfare Technology Research Program (LGJ2OH160001). This study has been presented in part at the ASCO annual meeting 2020.

We would like to thank Editage (www.editage.com) for their writing support.

\section{Conflicts of interest/Competing interests}

The authors declare that they have no conflict of interest.

\section{Availability of data and material}


Data is available in Taiwan Cancer Registry: http://tcr.cph.ntu.edu.tw/main.php?Page=A1

\section{Code availability}

Source codes are available on the website of Taiwan Cancer Registry:

http://tcr.cph.ntu.edu.tw/main.php?Page=A1

\section{Authors' contributions}

Data Access, Responsibility, and Analysis: $\mathrm{HC}$ and SHC had full access to all of the data in the study and take responsibility for the integrity of the data and the accuracy of the data analysis.

Concept and design: LL and SHC.

Acquisition, analysis, or interpretation of data: HC, TP, and SHC

Drafting of the manuscript: $\mathrm{LL}$ and SHC

Critical revision of the manuscript for important intellectual content: LL, TP and SHC

Statistical analysis: $\mathrm{HC}$ and TP

Obtained funding: LL and SHC

\section{Ethics approval}

Institutional Review Board of National Taiwan University Hospital (NTUH-REC No.: 201910027W).

\section{Consent to participate}

This study was exempted from an informed consent by the review board.

\section{Consent for publication}

Not applicable

\section{References}

1. Bhoo-Pathy N, Yip C-H, Hartman M, Uiterwaal CSPM, Devi BCR, Peeters PHM, Taib NA, van Gils CH, Verkooijen HM (2013) Breast cancer research in Asia: Adopt or adapt Western knowledge? European Journal of Cancer 49:703-709. doi: https://doi.org/10.1016/j.ejca.2012.09.014

2. Bray F, Ferlay J, Soerjomataram I, Siegel RL, Torre LA, Jemal A (2018) Global cancer statistics 2018: GLOBOCAN estimates of incidence and mortality worldwide for 36 cancers in 185 countries. CA: a cancer journal for clinicians 68:394-424. 
3. Bueno-de-Mesquita JM, van Harten WH, Retel VP, van 't Veer LJ, van Dam FS, Karsenberg K, Douma KF, van Tinteren H, Peterse JL, Wesseling J, Wu TS, Atsma D, Rutgers EJ, Brink G, Floore AN, Glas AM, Roumen RM, Bellot FE, van Krimpen C, Rodenhuis S, van de Vijver MJ, Linn SC (2007) Use of 70-gene signature to predict prognosis of patients with node-negative breast cancer: a prospective community-based feasibility study (RASTER). Lancet Oncol 8:1079-1087. doi: 10.1016/S14702045(07)70346-7

4. Cardoso F, van't Veer LJ, Bogaerts J, Slaets L, Viale G, Delaloge S, Pierga JY, Brain E, Causeret S, DeLorenzi M, Glas AM, Golfinopoulos V, Goulioti T, Knox S, Matos E, Meulemans B, Neijenhuis PA, Nitz U, Passalacqua R, Ravdin P, Rubio IT, Saghatchian M, Smilde TJ, Sotiriou C, Stork L, Straehle C, Thomas G, Thompson AM, van der Hoeven JM, Vuylsteke P, Bernards R, Tryfonidis K, Rutgers E, Piccart M, Investigators M (2016) 70-Gene Signature as an Aid to Treatment Decisions in Early-Stage Breast Cancer. The New England journal of medicine 375:717-729. doi: 10.1056/NEJMoa1602253

5. Cardoso F, van't Veer LJ, Bogaerts J, Slaets L, Viale G, Delaloge S, Pierga J-Y, Brain E, Causeret S, DeLorenzi M (2016) 70-gene signature as an aid to treatment decisions in early-stage breast cancer. New England Journal of Medicine 375:717-729.

6. Early Breast Cancer Trialists' Collaborative G (2005) Effects of chemotherapy and hormonal therapy for early breast cancer on recurrence and 15-year survival: an overview of the randomised trials. Lancet 365:1687-1717. doi: 10.1016/S0140-6736(05)66544-0

7. Goldhirsch A, Wood WC, Coates AS, Gelber RD, Thurlimann B, Senn HJ (2011) Strategies for subtypes-dealing with the diversity of breast cancer: highlights of the St. Gallen International Expert Consensus on the Primary Therapy of Early Breast Cancer 2011. Annals of oncology : official journal of the European Society for Medical Oncology / ESMO 22:1736-1747. doi: mdr304 [pii] 10.1093/annonc/mdr304

8. Gradishar WJ, Anderson BO, Abraham J, Aft R, Agnese D, Allison KH, Blair SL, Burstein HJ, Dang C, Elias AD, Giordano SH, Goetz MP, Goldstein LJ, Isakoff SJ, Krishnamurthy J, Lyons J, Marcom PK, Matro J, Mayer IA, Moran MS, Mortimer J, O'Regan RM, Patel SA, Pierce LJ, Rugo HS, Sitapati A, Smith KL, Smith ML, Soliman H, Stringer-Reasor EM, Telli ML, Ward JH, Young JS, Burns JL, Kumar R (2020) Breast Cancer, Version 3.2020, NCCN Clinical Practice Guidelines in Oncology. J Natl Compr Canc Netw 18:452-478. doi: 10.6004/jnccn.2020.0016

9. Holowatyj AN, Cote ML, Ruterbusch JJ, Ghanem K, Schwartz AG, Vigneau FD, Gorski DH, Purrington KS (2018) Racial Differences in 21-Gene Recurrence Scores Among Patients With Hormone ReceptorPositive, Node-Negative Breast Cancer. Journal of clinical oncology : official journal of the American Society of Clinical Oncology 36:652-658. doi: 10.1200/JC0.2017.74.5448

10. Huang TT, Lei L, Chen CA, Lu TP, Jen CW, Cheng SH (2020) A new clinical-genomic model to predict 10-year recurrence risk in primary operable breast cancer patients. Sci Rep 10:4861. doi:

10.1038/s41598-020-61535-9

11. Iqbal J, Ginsburg O, Rochon PA, Sun P, Narod SA (2015) Differences in breast cancer stage at diagnosis and cancer-specific survival by race and ethnicity in the United States. Jama 313:165-173. doi: 10.1001/jama.2014.17322

Page $11 / 16$ 
12. Jasem J, Fisher CM, Amini A, Shagisultanova E, Rabinovitch R, Borges VF, Elias A, Kabos P (2017) The 21-gene recurrence score assay for node-positive, early-stage breast cancer and impact of RXPONDER Trial on chemotherapy decision-making: have clinicians already decided? Journal of the National Comprehensive Cancer Network 15:494-503.

13. Kwon MJ, Lee JE, Jeong J, Woo SU, Han J, Kang BI, Kim JE, Moon Y, Lee SB, Lee S, Choi YL, Kwon Y, Song K, Gong G, Shin YK (2019) Comparison of GenesWell BCT Score With Oncotype DX Recurrence Score for Risk Classification in Asian Women With Hormone Receptor-Positive, HER2-Negative Early Breast Cancer. Front Oncol 9:667. doi: 10.3389/fonc.2019.00667

14. Laenkholm AV, Jensen MB, Eriksen JO, Rasmussen BB, Knoop AS, Buckingham W, Ferree S, Schaper C, Nielsen TO, Haffner T, Kibol T, Moller Talman ML, Bak Jylling AM, Tabor TP, Ejlertsen B (2018) PAM50 Risk of Recurrence Score Predicts 10-Year Distant Recurrence in a Comprehensive Danish Cohort of Postmenopausal Women Allocated to 5 Years of Endocrine Therapy for Hormone ReceptorPositive Early Breast Cancer. Journal of clinical oncology : official journal of the American Society of Clinical Oncology 36:735-740. doi: 10.1200/JC0.2017.74.6586

15. Mansour EG, Gray R, Shatila AH, Tormey DC, Cooper MR, Osborne CK, Falkson G (1998) Survival advantage of adjuvant chemotherapy in high-risk node-negative breast cancer: ten-year analysis-an intergroup study. Journal of clinical oncology 16:3486-3492.

16. Orucevic A, Heidel RE, Bell JL (2016) Utilization and impact of 21-gene recurrence score assay for breast cancer in clinical practice across the United States: lessons learned from the 2010 to 2012 National Cancer Data Base analysis. Breast Cancer Res Treat 157:427-435. doi: 10.1007/s10549016-3833-9

17. Sparano JA, Gray RJ, Makower DF, Pritchard KI, Albain KS, Hayes DF, Geyer CE, Jr., Dees EC, Goetz MP, Olson JA, Jr., Lively T, Badve SS, Saphner TJ, Wagner LI, Whelan TJ, Ellis MJ, Paik S, Wood WC, Ravdin PM, Keane MM, Gomez Moreno HL, Reddy PS, Goggins TF, Mayer IA, Brufsky AM, Toppmeyer DL, Kaklamani VG, Berenberg JL, Abrams J, Sledge GW, Jr. (2018) Adjuvant Chemotherapy Guided by a 21-Gene Expression Assay in Breast Cancer. The New England journal of medicine 379:111-121. doi: 10.1056/NEJMoa1804710

18. Sparano JA, Gray RJ, Makower DF, Pritchard KI, Albain KS, Hayes DF, Geyer CE, Jr., Dees EC, Perez EA, Olson JA, Jr., Zujewski J, Lively T, Badve SS, Saphner TJ, Wagner LI, Whelan TJ, Ellis MJ, Paik S, Wood WC, Ravdin P, Keane MM, Gomez Moreno HL, Reddy PS, Goggins TF, Mayer IA, Brufsky AM, Toppmeyer DL, Kaklamani VG, Atkins JN, Berenberg JL, Sledge GW (2015) Prospective Validation of a 21-Gene Expression Assay in Breast Cancer. The New England journal of medicine 373:2005-2014. doi: 10.1056/NEJMoa1510764

19. Sparano JA, Gray RJ, Ravdin PM, Makower DF, Pritchard KI, Albain KS, Hayes DF, Geyer CE, Jr., Dees EC, Goetz MP, Olson JA, Jr., Lively T, Badve SS, Saphner TJ, Wagner LI, Whelan TJ, Ellis MJ, Paik S, Wood WC, Keane MM, Gomez Moreno HL, Reddy PS, Goggins TF, Mayer IA, Brufsky AM, Toppmeyer DL, Kaklamani VG, Berenberg JL, Abrams J, Sledge GW, Jr. (2019) Clinical and Genomic Risk to Guide the Use of Adjuvant Therapy for Breast Cancer. The New England journal of medicine 380:2395-2405. doi: 10.1056/NEJMoa1904819 
20. Venables WN, Smith DM, Team TRC (2019) An Introduction to R - Notes on R: A Programming Environment for Data Analysis and Graphics Version 3.6.1.

21. Wang SY, Chen T, Dang W, Mougalian SS, Evans SB, Gross CP (2019) Incorporating Tumor Characteristics to Maximize 21-Gene Assay Utility: A Cost-Effectiveness Analysis. J Natl Compr Canc Netw 17:39-46. doi: 10.6004/jnccn.2018.7077

\section{Figures}

\begin{tabular}{|c|c|}
\hline $\begin{array}{l}\text { All breast cancer patients (2008-2012) } \\
\qquad \mathrm{N}=90,837 \text { subjects }\end{array}$ & $\begin{array}{l}\text { After exclusion of patients with date of death earlier than date } \\
\text { of diagnosis. } N=20,121 \text { subjects }\end{array}$ \\
\hline Pathology stage T1-2N0 & $\sqrt{2}$ \\
\hline Pathology stage T1-2NO & Newly diagnosed breast cancer \\
\hline $\mathrm{N}=23,672$ subjects & $\mathrm{N}=18,637$ subjects \\
\hline After exclusion of patients who did not undergo surgery. $\mathrm{N}=$ & $\checkmark$ \\
\hline 23,606 subjects & Female \\
\hline$\checkmark$ & $N=18,564$ subjects \\
\hline After exclusion of patients with missing data on date of & 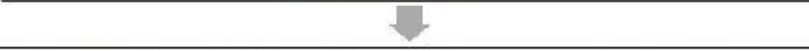 \\
\hline surgery. $\mathrm{N}=23,603$ subjects & After exclusion of patients with HER2-negative tumors who \\
\hline $\begin{array}{l}\begin{array}{l}\text { After exclusion of patients with preope rative chemotherapy. } \mathrm{N} \\
\qquad=22,332 \text { subjects }\end{array}\end{array}$ & $\sqrt{2}$ \\
\hline$\sqrt{2+20}$ & After exclusion of patients with ER-/PR-negative who received \\
\hline $\begin{array}{l}\text { After exclusion of patients with who died before receiving any } \\
\text { treatment. } \mathrm{N}=22,326 \text { subjects }\end{array}$ & normone therapy. $N=18,409$ subjects \\
\hline$\sqrt{2}$ & After exclusion of patients with synchronous bilateral breast \\
\hline After exclusion of patients with primary treatment in different & cancers. $\mathrm{N}=18,466$ subjects \\
\hline hospitals. $\mathrm{N}=21,848$ subjects & $\sqrt{2}+2$ \\
\hline $\begin{array}{l}\text { After exclusion of patients with cancer unknown primary origin. } \\
\qquad \mathrm{N}=21,712 \text { subjects }\end{array}$ & $\begin{array}{l}\text { Complete data on tumor grade and tumor size } \\
\qquad \mathrm{N}=17,532 \text { subjects }\end{array}$ \\
\hline+2 & 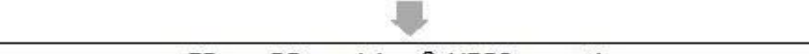 \\
\hline $\begin{array}{l}\text { After exclusion of patients who transferred to other hospitals. } \\
\qquad N=20,122 \text { subjects }\end{array}$ & $\begin{array}{l}\text { ER- or PR-positive \& HER2-negative } \\
\qquad \mathrm{N}=8,295 \text { subjects }\end{array}$ \\
\hline
\end{tabular}

\section{A minimum follow-up time $\geq 5$ years if event-free: $\mathrm{N}=2,830$}

\section{Figure 1}

Study flow of patient selection. Subjects were selected from the Taiwan Cancer Database between 2008 and 2012. There were 8295 patients included in this study; the last follow-up information was obtained in December 2019. (Abbreviation: HER2: human epidermal growth factor receptor 2; ER: estrogen receptor; PR: progesterone receptor) 
$\begin{array}{ll}\text { Figure 2A } & \text { Dutch definition } \\ & \text { Breast cancer-specific survival }\end{array}$

Figure 2B

Dutch definition overall survival
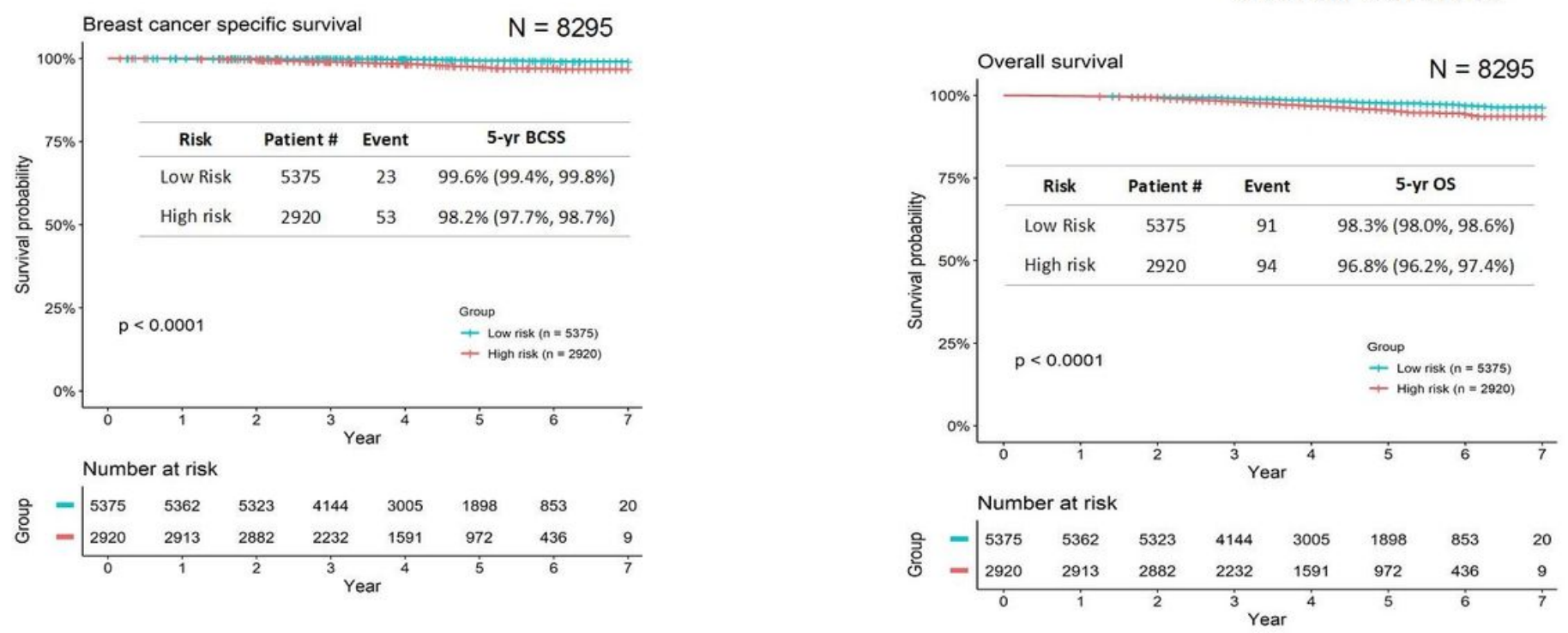

Figure 2

Breast cancer-specific survival (2A) and overall survival (2B) of low- and high-risk patients according to the Dutch criteria 
Figure 3

\section{Dutch definition: low risk and high risk with or without chemotherapy Breast Cancer-Specific Survival}

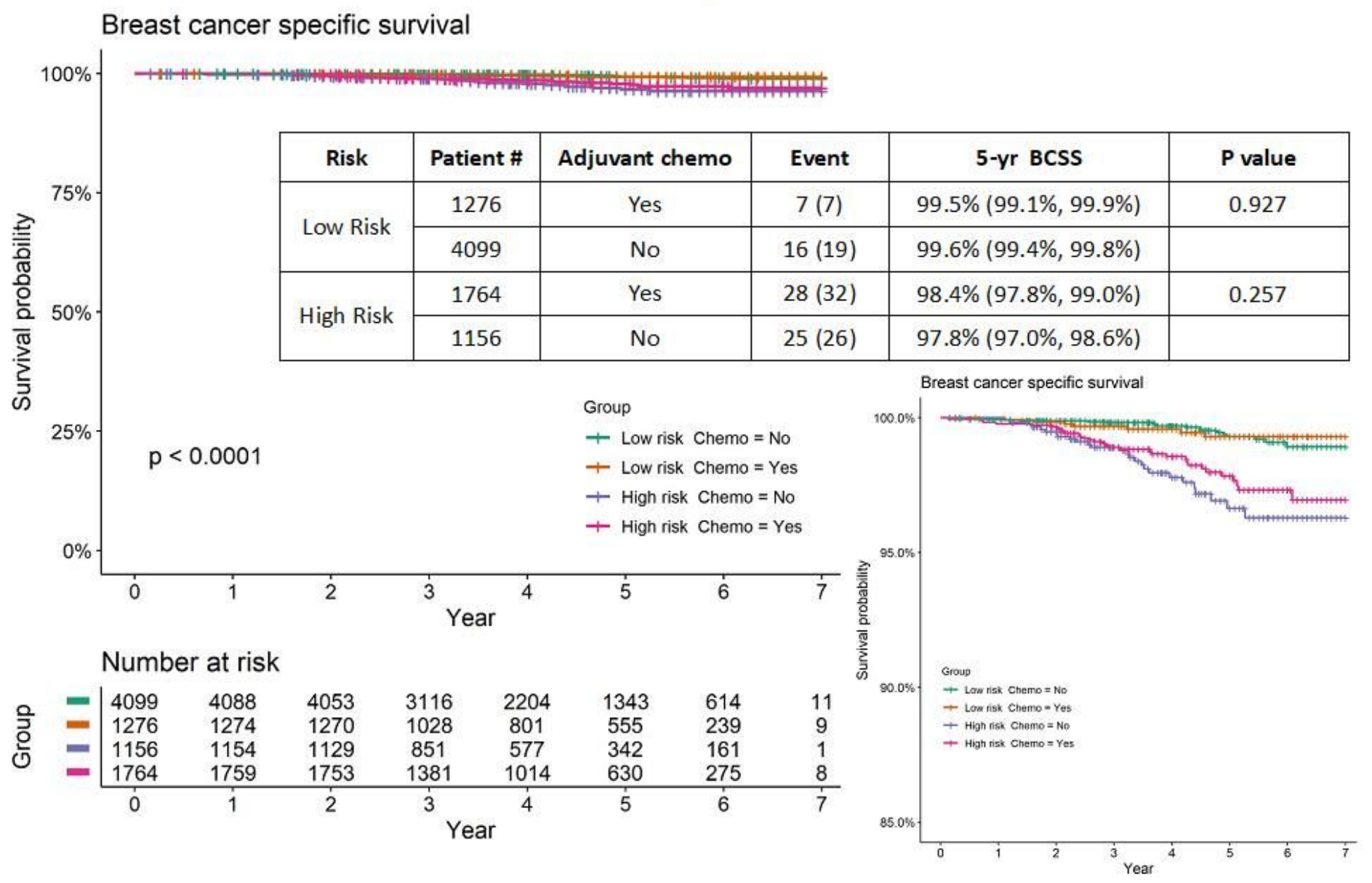

\section{Figure 3}

Breast cancer-specific survival of low- and high-risk patients based on the administration of adjuvant chemotherapy. There is no significant difference in breast cancer-specific survival between low-risk patients with or without chemotherapy. The magnified figure shows a small difference in breast cancerspecific survival between high-risk patients with or without chemotherapy; the p value was 0.257 . 
Figure 4

Dutch definition: low risk and high risk with or without chemotherapy Overall Survival

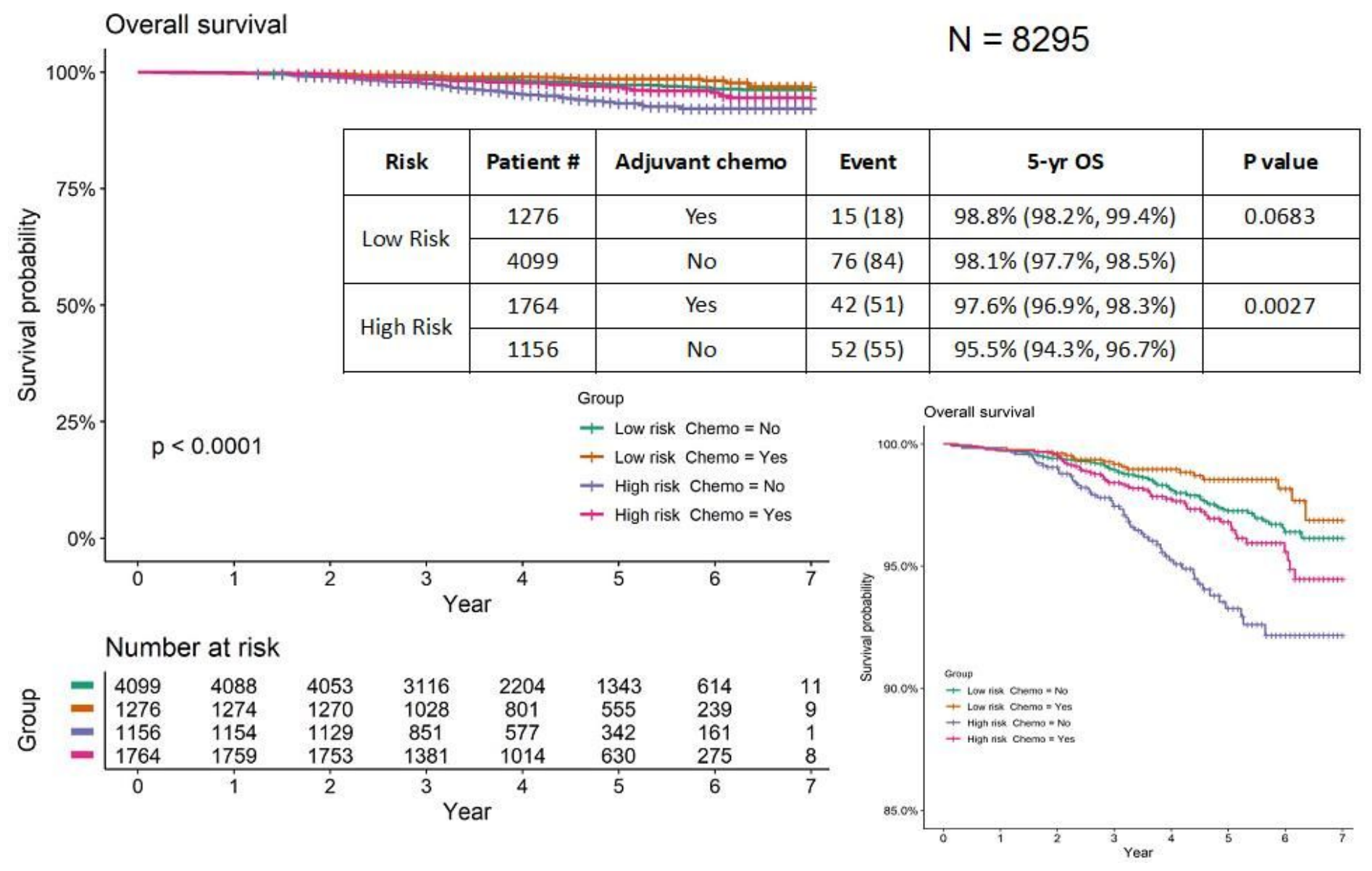

Figure 4

Overall survival of both low- and high-risk patients based on the administration of adjuvant chemotherapy. A trend of survival difference between low-risk patients with or without chemotherapy is observed $(P=0.0683)$. The difference in the overall survival of high-risk patients with or without chemotherapy is significant $(P=0.0027)$. 